\title{
'Brexit', a Stress Test for State Aid Control?
}

The outcome of the June referendum in the United Kingdom and the subsequent statements of the Government imply that the UK is likely to leave the European Union in the not too distant future. The precise date and terms of the break up are not yet settled. Determining those would certainly take long and complex negotiations lie ahead that have not even started yet.

While being saddened by Brexit, we have to respect the decision of our British friends. It seems nevertheless clear that all this is rather bad news for those, like us, who believe in European integration and - in our opinion - probably also for the United Kingdom itself.

What would be the likely impact of Brexit on State aid control? It is obviously impossible to know at this moment, at a time in which we guess that not even the negotiating positions of both sides have yet been determined and even less so as regards State aid. It is not however totally impossible, if one knows a few things about State aid, to make an educated guess of what kinds of issues and risks we may face in a few months time.

It seems obvious that Brexit would modify in the medium term the shape of future EU State aid policy. Indeed, State aid has always been a politically sensitive area of EU Law, in which, despite the very important role of the European Commission, the position of the different Member States has played a great role. And probably no other Member States has played a greater role than the UK itself during the last decade, on issues like the emphasis on the 'refined economic approach' or on a reorientation of policy towards the so called 'good aid'. As in other areas of EU policy, the UK has traditionally been considered as a pro competition country; not all Member States - in particular big Member States - necessarily always share the same instincts.

So, like in other areas of EU Law, the departure of the UK is likely to change the political balance in which State aid policy takes shape. For instance, Brexit might pave the way for a more intense use of State aid in the tax area, something that this country always considered delicate but that is now high on the agenda of the European Commission.

The above refers to future changes in EU State aid policy. How about the future of State aid control in the UK itself? How about its future institutional framework? And what of the relationship between the EU and the UK as regards State aid? The answers to these important questions will largely depend on the kind of relationship that both sides finally agree on a key issue: access to the internal market. Is the UK going to aim at keeping access to the internal market and therefore at some form of 'soft Brexit' or is it going to prefer a more distant relationship, normally dubbed 'hard Brexit'?

Some recent statements seem to suggest that the British Government may be taking the second option. It is too early for us to know if this is going to be the case and if it would be kept to the end. However, if a 'hard Brexit' finally materialised, it would at least have the advantage of its brutal simplicity. In such a scenario the UK, like any third country, would not have any privileged access to the internal market and would not be obliged to apply any State aid control. It would only be bound by the WTO anti-subsidy rules. Of course, even in the event of a 'hard Brexit' nothing would prevent the UK from recreating a domestic system of State aid control if it considered useful for its economy. This would not be surprising, given the past record of British Governments advocating for State aid control, even if certain recent statements suggest that this attitude might perhaps change in the future.

But, what if - as may be the case - we ended up with some kind of 'soft Brexit' preserving access to the internal market? What kind of arrangements would be needed then? It is at this point that things may become more complex and more delicate. 
Indeed, as our UK correspondent George Peretz explains in an interesting and detailed opinion published in this EStAL issue, access to the EU internal market seems hardly conceivable without an agreement guaranteeing the application of State aid rules in the UK. So, in case of a 'soft Brexit', it would be necessary to foresee some system of State aid control in the UK.

The challenge in that scenario would be setting an institutional framework that is both operational and politically feasible.

The problem is that, as virtually everybody familiar with actual State aid knows, in order to be credible, its control must be by definition supranational. An organism of the State would hardly be able to seriously control an aid granted by the same State, not at least if we speak of really important and politically sensitive files.

Would the UK accept being subject to supranational State aid control after Brexit? This would greatly facilitate things but it looks rather unlikely.

In such a scenario, accession to the existing European Economic Area (EEA) could in theory be an option, since State aid control would be fulfilled by an international organisation like the EFTA Surveillance Authority, in which the UK would become a member if the current Member States (Norway, Iceland and Liechtenstein) agreed. It would be a curious turn of events, since the UK was a founding member of EFTA many years ago before its accession to the then European Communities. It is however far from obvious, politically speaking, whether the UK would be prepared to join the EEA at the same moment that it has decided to leave the EU. The same difficulty would probably apply to other alternative ad hoc control mechanisms that one might imagine, to the extent that they would have to be supranational. Indeed, it is precisely the same 'supranational' character that seems indispensable for the effectivity and credibility of State aid control that would make it politically difficult to accept by a country whose aim is to 'take back control'.

In view of this objectively difficult situation, it would not be too surprising if some kind of self-control by a national 'independent agency' were put on the table as a possibility at some point in time. If so, a word of caution seems more than appropriate about the inherent risk arising from such an idea.

Past examples of self-control are not many and not always very fortunate. The Europe Agreements with the candidate countries in Central and Eastern Europe foresaw such a system, which worked for a few years until these countries acceded to the EU (and remain in place for those still on the waiting list). Other neighbour countries also committed to establishing some kind of self-control, which has however not actually materialised. Even when the above mechanisms have been put into place, the outcomes have not always been respected by the aidgranting political authorities. However, the limited relative weight of those economies compared with that of the EU, the incentive of future membership and/or the institutional and political leverage kept by the EU over those countries made sure that no major accident occurred.

Allowing a big economy like the UK to undertake self-control of State aid would be a totally different story. On the one hand there would not be any incentive in terms of future membership of the EU that would play as leverage. On the other hand, and even assuming a lot of good will on both sides, the risk of diverging decisions on delicate and important issues like fiscal State aid would be very difficult to avoid and could generate serious tensions. It is for these reasons that such a solution, if adopted, would probably test the limits of the logic of State aid control.

Such a hypothetical move may also become a catalyst for further decentralisation of State aid control within the EU, a controversial move already in motion as a result of the recent Gen- 
eral Block Exemption Regulation (GBER) which has exempted from notification around 85\% of the cases previously notified to the Commission. The problem is that the remaining $15 \%$ of cases not covered by the GBER include the very sensitive and very political ones. If a country like the UK were able get access to the internal market without being subject to an external control on State aid of this kind, it would be difficult in the future for the EU institutions to oppose similar solutions for the EU Member States.

Again, we believe that, in order to be credible and effective, State aid control must be by definition supranational, at least as regards the important and sensitive cases. A further decentralisation of State aid control into the hands of national authorities could easily get 'out of control' and herald the end of State aid control at least as we know it now.

This Journal would certainly not be in favour of any further move in that direction. Since we tend to believe that State aid control is indispensable, we also consider that it must remain in the hands of a supranational entity independent from the national authorities granting the aid. The European Commission perfectly fits this profile and, despite some errors from time to time, its overall past record of running State aid policy during the last 60 years is not only positive but rather impressive. If the Commission did not exist, it should be invented now. We see no reason to undermine its mandate in times as complex as the ones in which we are living.

We do not know exactly what the future will bring us. However, it already seems clear that the Brexit negotiations may imply some serious risks for the future of State aid control. Like systematically important banks have done in the past, the EU State aid system is going to undertake a serious 'stress test' from which we hope it will emerge alive and reinforced. After all, "what does not kill you makes you stronger!"

Jose Luis Buendía Sierra 